\title{
As doações testamentárias na cidade de Mariana entre os séculos XVIII e XIX ${ }^{1}$
}

\section{Testament donations in the city of Mariana between the 18th and 19 th Centuries}

\author{
Karina Aparecida de Lourdes Ferreira*
}

\begin{abstract}
Resumo
O presente artigo consiste em uma reflexão sobre a prática de doações póstumas instituídas pela população testamentária da cidade de Mariana entre 1748 e 1848. Essa modalidade de caridade, situada no momento específico de preparação para a própria morte, ajudava a compor o quadro de medidas tomadas com vistas a uma boa morte segundo as aspirações então vigentes. Desse ponto de vista, e considerando que, ao contrário da herdade, as esmolas eram de livre nomeação, pretende-se analisar as preferências a respeito dos favorecidos pelas doações ao longo do tempo. Visa-se, particularmente, estabelecer comparações entre as doações direcionadas à Igreja e a pessoas próximas, buscando salientar as diferenças de possibilidades, significados e expectativas de cada uma.
\end{abstract}

Palavras-chave: testamentos; doações; Mariana;

\begin{abstract}
This article is a reflection on the practice of posthumous donations instituted by the testamentary population of the city of Mariana between 1748 and 1848. This type of charity act, at the specific moment of preparation for one own death, helped to compose the picture of the measures taken intending to achieve a good death according to the prevailing conceptions. From this point of view, and considering that, unlike homestead, alms were freely donated, it is intended to analyze the preferences regarding those whom were favored by donations over time. Particularly, it is intended to make comparisons between the donations directed to the Church and those close to them, trying to highlight the differences of possibilities, meanings and expectations of each one.
\end{abstract}

Keywords: wills; donations; Mariana;

\footnotetext{
${ }^{1}$ Este artigo é parte constituinte de uma pesquisa mais ampla, intitulada Morte, memória e familia: a prática e os atores testamentários em Mariana, 1748-1848, desenvolvida junto ao Programa de Pós-Graduação em História da Universidade Federal de Minas Gerais, com apoio financeiro do Conselho Nacional de Desenvolvimento Científico e Tecnológico (CNPq).

*Mestra em História pela Universidade Federal de Minas Gerais. E-mail: karina.ferreira.alf@gmail.com
} 
Toda sociedade desenvolve simbologia própria sobre a existência individual e seu encerramento, obedecendo ao imperativo humano de eternização através da negação da corrupção do tempo. Lançando mão de seus próprios meios, cada cultura, tendo tomado consciência do fato bruto e certeiro da morte, elabora suas práticas de cuidado para com os cadáveres, suas representações dos indivíduos mortos, seu conjunto de mecanismos para lidar com o processo de luto e, sobretudo, estratégias de reordenamento social. Em toda parte a morte foi objeto de ritos de passagem correspondentes à crença na sobrevida ou no renascimento.

Em Mariana, como em outras partes do Ocidente cristão, os cuidados para com os mortos e as precauções tomadas pelos indivíduos ao anteverem seu falecimento respondiam a anseios compartilhados pelo aparato desenvolvido nos meios católicos que apregoava que uma boa morte requeria certo nível de preparação. A elaboração de testamentos na proximidade da morte - repletos de cláusulas religiosas e de desencargos de consciência em função disso, foi prática amplamente difundida. Nesses documentos, os testadores encomendavam sua alma, recorriam à intercessão de santos protetores, professavam sua fé, assentavam resoluções quanto ao local e ritual de sepultamento, encomendavam missas, solicitavam assistência de associações religiosas das quais eram irmãos professos. Para além das cláusulas especificamente espirituais, nos testamentos eram resolvidos assuntos pendentes (como o acerto de dívidas), faltas eram reparadas (como o reconhecimento de filhos naturais), e se dispunha dos bens por vezes como demonstração de desprendimento, justiça e caridade.

Uma boa morte, além da conduta do testador em vida, continuava ainda a ser tributária do mundo terreno pelas orações e preces que se faziam. A doutrina da comunhão dos santos, ao conceber a união de todos os católicos em um só corpo, sustentou a crença da atuação de solidariedades mútuas entre vivos e mortos, santos e pecadores. A crença na intercessão pelos mortos respaldava as expectativas salvacionistas e os cuidados fúnebres que pressupunham, guardadas suas especificidades, certa participação coletiva e a mobilização da lembrança da pessoa falecida.

o complexo da ritualística fúnebre pode ser dividido em três conjuntos de cuidados que se desenrolavam conforme significados distintos. 0 primeiro deles, que precedia à morte do indivíduo, consistia na administração ao enfermo dos últimos sacramentos pelo sacerdote designado para 
a função. ${ }^{2}$ A aplicação dos sacramentos - penitência, eucaristia e extrema unção - ocorria no leito de morte, tendo em vista ser esse, a hora da passagem, o momento crucial onde, mediante às investidas do demônio, o destino do moribundo seria decidido. ${ }^{3}$ As práticas realizadas na presença do corpo sem vida, por sua vez, formam o segundo conjunto, composto pelo amortalhamento, acompanhamento do féretro, ofícios fúnebres e sepultamento, os quais representavam um estágio de suspensão, nos termos de Sérgio da Mata, "de ambivalência, em que já não se é o que era antes, mas ainda não se é aquilo que o rito nos acena e promete". ${ }^{4}$ Situados entre a separação do mundo dos vivos e a agregação no mundo dos mortos, tinham como finalidade cuidar mais incisivamente dessa transição, durante a qual o morto estava ainda desintegrado da estrutura social. ${ }^{5}$ Por fim, o último grupo de medidas fúnebres, do qual pode-se destacar a celebração de missas e a distribuição de legados, era realizado depois do corpo colocado em descanso eterno, se ocupando da incorporação do defunto no mundo dos mortos.

Embora deva-se insistir que a noção corrente de boa morte encerrasse o apelo à participação coletiva e o recurso à recordação da pessoa falecida, esses dois princípios representavam esforços diferentes conforme o momento dos ritos fúnebres. Os cuidados promovidos anterior ou imediatamente à morte, se desdobravam conforme uma duração encurtada, com grande envolvimento comunitário, mas prescindindo de grandes esforços mnemônicos, uma vez que o morto ainda era presença e de quem, aliás, se buscava a separação. 0 conjunto de medidas tomadas após o enterramento, por seu turno, tornavam a lembrança do morto especialmente valorizada, por ser também cada vez mais precária e, por isso, necessária. As encomendas de missas mandadas celebrar em memória do defunto são a expressão mais visível do exercício mnemônico ensejado no post-mortem. A realização dessas celebrações, as quais poderiam

\footnotetext{
${ }^{2} \mathrm{~A}$ assistência espiritual às pessoas em risco de morte era uma das grandes preocupações sistematizadas nas Constituições Primeiras. O documento insistia para que os párocos, sob pena de suspensão e prisão em caso de negligência, visitassem frequentemente quem estivesse em tais circunstâncias, cuidando para que nenhum paroquiano morresse sem antes ter recebido os últimos sacramentos. DA VIDE. Sebastião Monteiro. Constituições Primeiras do Arcebispado da Bahia. Feitas, e ordenadas pelo ilustríssimo, e reverendíssimo senhor D. Sebastião Monteiro da Vide: Propostas e Aceitas em o Synodo Diocesano, que o dito Senhor celebrou em 12 de junho do anno de 1707. Typografia de Antônio Louzada Antunes, São Paulo: 1853. Livro I, título XXXIX, p. 67. ${ }^{3}$ CASTRO, Estevão de. Breve aparelho e modo fácil para ajudar a bem morrer um cristão, com a recopilação da matéria de tratamentos, e penitência, várias orações devotas, tiradas da Escritura Sagrada, e do Ritual Romano de N. S. P. Paulo V, acrescentada da devoção de várias missas. Lisboa: por Mattheus Pinheiro: a custa de Adrião de Abreu, 1627. Folha 1.
}

${ }^{4}$ MATA, Sérgio da. História \& Religião. Belo Horizonte: Autêntica Editora, 2010. p. 131.

${ }^{5}$ Cf.: TURNER, Victor. O Processo Ritual. Petrópolis: Vozes, 1974. pp. 116-159. 
se estender por anos a fio após a morte do fiel, era a feição mais acabada da memória litúrgica ${ }^{6}$, do "lembrar por meio da prece". 7 A instituição de missas, não apenas abreviava a estadia da alma no Purgatório como também impunha aos vivos a obrigatoriedade da recordação, ${ }^{8}$ esforço do qual dependia, afinal, a própria cerimônia religiosa em questão.

A distribuição de esmolas, guardada sua especificidade, atuava na mesma direção das missas, como meio para perpetuação de uma memória, ligada por sua vez, à virtude da caridade, à imagem de benfeitoria social e ao sentimento de gratidão ou dívida. Para além disso, segundo Tânia Santana, ao passo que as esmolas distribuídas em vida adicionavam status ao doador - porque sancionavam sua riqueza, fortaleciam seu poder e os vínculos de subordinação, contribuindo também para a construção de uma aparência relacionada a valores ligados à generosidade -, os legados deixados em testamento, de outro modo, implicavam na perpetuação de uma memória do morto que, ligada aos mesmos valores, se prestava à aglutinação familiar em torno de sua figura. ${ }^{9}$

Tendo em vista o exposto, esse artigo pretende analisar as doações instituídas em testamento, atrelando-se ao seu sentido cristão mais evidente, sua função social e de reforço das solidariedades familiares. Foram estudados 269 registros testamentários produzidos por moradores da cidade de Mariana ${ }^{10}$ entre os anos de 1748 e 1848, nos quais buscou-se identificar a frequência das esmolas ao longo do tempo, seus principais beneficiários e as possíveis razões envolvidas nessas escolhas. É preciso salientar que esse estudo é parte de uma investigação maior que demonstrou como o ato de preparação para uma boa morte e as recomendações para o cerimonial fúnebre davam

\footnotetext{
${ }^{6}$ SCHMITT, Jean-Claude. Os vivos e os mortos na sociedade medieval. Trad. Maria Lucia Machado. São Paulo, Companhia das Letras, 1999. p. 19.

${ }^{7}$ OEXLE, Otto Gerhard. A presença dos mortos. In: BRAET, Herman \& VERBEKE, Werner (eds.). A Morte na Idade Média. Trad. Heitor Megale, Yara Frateschi Vieira, Maria Clara Cescato. São Paulo: Edusp, 1996. p. 34.

${ }^{8}$ DAVES, Alexandre Pereira. Vaidades das Vaidades: os homens, a morte e a religião nos testamentos da Comarca do Rio das Velhas (1716-1755). Dissertação (Mestrado em História). Belo Horizonte: UFMG, 1998. p. 101.

${ }^{9}$ SANTANA, Tânia Maria Pinto de. Charitas et misericordia: as doações testamentárias em Cachoeira no século XVIII. Tese (Doutorado em História). Salvador: UFBA, 2016. p. 67.

${ }^{10}$ Dos testamentos utilizados, o maior volume é formado por registros anexados aos inventários do Cartório do $1^{2}$ Ofício de Mariana, acessados em sua totalidade para o período em questão na plataforma virtual do LAMPEH (Laboratório Multimídia de Pesquisa Histórica). Outro conjunto de documentos foi selecionado nos livros de registros de testamentos mantidos no Arquivo Histórico da Casa Setecentista de Mariana. Por fim, alguns poucos testamentos foram encontrados entre os registros paroquiais de óbitos da Paróquia de Nossa Senhora da Assunção, consultados na plataforma virtual do FamilySearch, entre o acervo de microfilmagens realizadas pela Sociedade Genealógica de Utah.
} 
a ver um processo mais amplo de inflexão familiar naquela sociedade. ${ }^{11}$ Esse fortalecimento e exaltação dos vínculos familiares que exerceu pressão sobre as atitudes diante da morte, resultando em importantes deslocamentos, não se restringiu, contudo, a essa dimensão específica da vida dos indivíduos, como outros estudos já apontaram. ${ }^{12}$

É preciso ainda, para dar prosseguimento à exposição, marcar a diferença entre a nomeação de herdeiros e de beneficiários de esmolas. A legislação portuguesa estipulava para a divisão de herança que, no caso de pessoas casadas, metade dos bens do falecido pertencia ao cônjuge, da metade restante, dois terços compunham a legítima, parcela que cabia aos herdeiros diretos, ascendentes ou descendentes, e, finalmente, o terço restante era a chamada terça, que poderia ser usada livremente pelo moribundo. Grande parte dos testadores aplicava sua terça em gastos com sua alma, sobretudo encomendando missas. ${ }^{13}$ Havia, como se vê, claros constrangimentos legais impostos à nomeação dos herdeiros, as doações, por outro lado, eram retiradas do montante de livre disposição, logo, poderiam ser direcionadas conforme a vontade do testador.

Uma passagem breve sobre os dados referentes à nomeação dos herdeiros demonstra o argumento. Entre a ampla maioria dos testadores que indicaram explicitamente a destinação da herança (266 casos), 202 (75,94\%) nomearam familiares, distribuídos entre filhos (41,35\%), parentes colaterais $(24,81 \%)$, cônjuges $(5,26 \%)$ e pais $(4,51 \%)$. Dos testadores que não nomearam familiares, 24 (9,02\%) indicaram a própria alma, 20 (7,52\%) o testamenteiro, e outros 20 nomearam outras pessoas específicas sem vínculo evidente. Algumas variações no interior da categoria da herança ocorreram a partir de uma quebra localizada na virada da década de 1760, desencadeada, ao que tudo indica, pelos aditamentos às Ordenações Filipinas promulgados pelo Marquês de Pombal. ${ }^{14} \mathrm{O}$ que se observou é que até o início da década de 1770,

\footnotetext{
${ }^{11}$ Cf.: FERREIRA, Karina Aparecida de Lourdes. Morte, memória e familia: a prática e os atores testamentários em Mariana, 1748-1848. Dissertação (Mestrado em História). Belo Horizonte: UFMG, 2019.

${ }^{12}$ Douglas Cole Libby e Zephyr Frank observaram um movimento de inflexão familiar, ou de fortalecimento e exaltação dos laços e dos relacionamentos familiares através da reconstituição das práticas de nomeação em São José del Rei entre 1751-1890. Cf.: LIBBY, Douglas C., FRANK, Zephyr. Naming Practices in Eighteenth- and Nineteenth-century Brazil: Names, Namesakes, and Families in the Parish of São Jose, Minas Gerais. Journal of Family History, 2015, Vol. 40 (1), pp. 64-91.

${ }^{13} \mathrm{CHAMON}$, Carla Simone. O bem da alma: a terça e a tercinha do defunto nos inventários do século XVIII da Comarca do Rio das Velhas. Varia História, Belo Horizonte, Vol. 9, n. 12, dez. 1993. pp. 58-65.

${ }^{14}$ Mais diretamente a Lei de 9 de setembro de 1769 que restringia o direito de instituir herdeiros universais e a natureza do patrimônio que poderia ser legado. Por meio dela foi ampliado o entendimento de herdeiros legítimos para parentes colaterais até o quarto grau. Persistindo a falta de herdeiros necessários, o testador
} 
a nomeação dos herdeiros se dividia quase exclusivamente entre a alma ${ }^{15}$ $(30,16 \%)$ e a família $(66,67 \%)$. Já no último quarto do século XVIII a nomeação da alma caiu para 6,94\% para desaparecer no século seguinte; surgiu a nomeação de pessoas fora do círculo familiar, prática que se estendeu para o século seguinte, permanecendo em torno dos 9,30\%; a indicação do testamenteiro como herdeiro teve um começo tímido, mas cresceu na virada do século, se mantendo perto dos 13\% durante toda a primeira metade do Oitocentos. Por fim, no que cabe à família, a década de 1770 representou um salto, que se conservou estável a partir de então em torno dos $78,8 \%$; além disso, em seu interior, a despeito da nomeação de descendentes diretos não ter apresentado oscilação digna de nota, registrou-se o crescimento dos parentes colaterais (de 14,29\% para 26,39\%), e, no século XIX, a fatia que na metade da centúria anterior era destinada aos pais, foi transferida para os cônjuges.

o que a herdade demonstrou, sem que fosse desenvolvida uma análise mais minuciosa, é uma já esperada mudança nas primeiras décadas do recorte cronológico diante das restrições instituídas pela atuação pombalina no que tangia ao direito de herança. A prática de nomeação da alma como herdeira universal, que era encabeçada por testadores solteiros, sem filhos e, majoritariamente, nascidos em Portugal, passou a dar lugar à indicação de parentes colaterais, destacadamente irmãos e sobrinhos. A proibição de nomeação da alma como herdeira, a ampliação dos herdeiros legítimos para até o quarto grau dos parentes colaterais e a restrição da natureza do patrimônio a ser transmitido foram acompanhados por uma importante alteração nas disposições da terça: "Pombal estipula que só uma terça parte dos bens da terça, ou hereditários ou adquiridos, pudesse reverter para bens de alma. E, ainda

poderia nomear como herdeiros universais outras pessoas "estranhas" da totalidade dos bens adquiridos, mas apenas de metade de seus bens herdados. LEWIN, Linda. Surprise Heirs: Illegitimacy, Patrimonial Rights, and Legal Nationalism in Luso-Brazilian Inheritance, 1750-1821. Vol. 1. Stanford: Stanford University Press, 2003. p. 34.

${ }^{15}$ Antes das restrições impostas pela atuação pombalina, a sucessão testamentária das Ordenações Filipinas permitia, na falta de herdeiros em linha direta, a instituição de herdeiros universais escolhidos a partir de um universo ilimitado de opções. A grande beneficiada desse sistema era a Igreja, para os cofres da qual se convertiam os bens dos testadores por meio de práticas como a fundação de capelas fúnebres, a nomeação de instituições religiosas ou da alma como herdeira universal. A prática de nomeação da alma como herdeira em Minas Gerais foi proeminente sobretudo entre os portugueses. De acordo com Linda Lewin, Kathleen Higgins identificou uma propensão singular entre os portugueses residentes em Sabará setecentista de nomeação da alma como herdeira universal. Na mesma direção, Donald Ramos confirmou a propensão de portugueses solteiros sem filhos amiúde entenderem os parentes colaterais que ficaram em Portugal como "estranhos", ou parentes "perdidos", preferindo dedicar a universalidade da legítima à sua própria alma. Ibidem. pp. 36-37. Os dados colhidos para a presente pesquisa caminharam nesse mesmo sentido: das pessoas que instituíram a alma como herdeira universal, nenhuma declarou descendentes ou ascendentes, a maioria era solteira $(91,67 \%)$ e composta por homens de Portugal (75\%). 
assim, para acautelar excessos, condiciona essa quota a um montante máximo de quatrocentos mil réis." ${ }^{16}$ Impôs-se, desse modo, uma restrição fundamental para os gastos com obras pias que visava à desamortização dos bens da Igreja.

Apesar de todo esse refreamento em termos dos montantes, dos herdeiros e da natureza da herdade, daquele pequeno percentual do patrimônio reservado à terça foi conservado o direito do testador de dispor livremente. Como intentou-se compreender a influência das relações entre as pessoas próximas sobre as escolhas testamentárias, aferindo a possibilidade de laços familiares mais sólidos terem sido decisivos nas transformações em torno da preparação para a boa morte, a atenção se voltou para a instituição de doações. Ainda que lhes coubessem uma parte pequena dos bens, ao contrário da instituição dos herdeiros em que os constrangimentos legais impuseram a primazia da parentela, no campo da nomeação dos beneficiários das doações "é que as escolhas individuais podem tornar-se decisivas, pois esta parcela é de livre nomeação."17

As doações instituídas no documento de última vontade não compunham cláusulas especificamente religiosas, tampouco meramente econômicas. Essas esmolas, embora também contribuíssem para o bem da alma do doador, se recobriam de um outro significado, decorrente de seu peso duplamente religioso e social, uma vez que os usos que delas eram feitos baseavam-se em escolhas pautadas nas relações sociais cotidianas. Em outros termos, se de um lado elas permaneciam como manifestação da virtude da caridade, de outro permitiam que o testador beneficiasse pessoas ou instituições com parte de sua fortuna.

De modo diferente das cláusulas testamentárias de natureza religiosa que, em geral, expressavam investimentos aplicados em práticas com envolvimento comunitário e convertidas para a salvação da alma, as doações instituídas no documento de última vontade, em princípio, eram dádivas unilaterais. Entendidas como manifestação da virtude da caridade, "com a qual amamos a Deos por amor delle, \& ao proximo por amor de Deos", ${ }^{18}$ representavam elevação espiritual através da manifestação altruística do mais sincero amor divino. A dádiva desinteressada em nome do amor de Deus, é

\footnotetext{
${ }^{16}$ ARAÚJO, Ana Cristina. A Morte em Lisboa: atitudes e representações (1700-1830). Lisboa: Notícias editorial, 1997. p. 276.

${ }^{17}$ SCOTT, Ana Silvia Volpi. Famílias, Formas de União e Reprodução Social no Noroeste Português (Séculos XVIII e XIX). NEPS - Universidade do Minho, Guimarães, 1999. p. 337.

18 “CARIDADE”. In: BLUTEAU, Raphael. Vocabulario portuguez, \& latino, aulico, anatomico, architectonico,... Coimbra: no Collegio das Artes da Companhia de Jesus: 1712-1728. Vol. 2. p. 148.
} 
claro, retornava ao doador na forma de frutos de natureza mística, em uma operação de conversão da assistência social em bem espiritual. "A ausência de reciprocidade em relação a dádivas e esmolas aplicadas a pobres, instituições religiosas e de assistência é compensada pelo aproveitamento espiritual que o doador retira da sua acção." ${ }^{19}$ Assentada igualmente na noção de trocas a partir das relações estreitas entre as dimensões da existência, as doações aos menos afortunados eram reconhecidas como medida eficaz para a ampliação da memória do morto ao incutir entre os seus beneficiários o sentimento de dívida ou gratidão. ${ }^{20}$ Logo se vê que as doações figuravam como atitudes beneficentes que ajudavam a compor uma imagem de virtuosismo piedoso, angariando vantagens rumo à salvação da alma na medida em que forneciam ganhos espirituais pela aproximação com o amor do Cristo e pelo estabelecimento entre os beneficiários de um conteúdo de memória ligada à gratidão ou à obrigação moral.

A natureza da caridade conforme manifestada nos testamentos torna qualquer tentativa de análise rigorosa dos legados impraticável, uma vez que não obedecia a nenhuma regularidade e nem sempre envolvia bens quantificáveis monetariamente. ${ }^{21}$ Desse modo, a atenção dedicada às doações foi direcionada para a natureza da relação existente entre testador e as pessoas ou instituições por ele favorecidas. Outros detalhes dessa prática, tais como, valor ou bem legado, quantidade de beneficiários por testador, possíveis condições impostas para o recebimento do benefício, não foram analisados. Embora seja reconhecida a capacidade de informar mais minuciosamente sobre o universo dos legados testamentários, esses elementos escapam ao escopo dessa pesquisa.

Tendo em vista as questões desenvolvidas, identificou-se os testadores que instituíram alguma doação e a categoria de seus respectivos beneficiários, distribuídos entre instituições religiosas, família, pessoas sem vínculo declarado, alma, pobres, escravos e outros. Do total de testadores, 142 (52,79\%) instituíram legatários. As informações apresentadas se referem ao número de doadores para cada tipo de beneficiário e não ao número de doações. Como parte dos testadores deixavam legados tanto para irmandades, por exemplo, como para parentes e pobres, se somados os beneficiários, estes ultrapassam o número total de testadores, não havendo aí, portanto, nenhum contrassenso. 0 destino dessas esmolas ao longo do tempo pode ser conferido na tabela:

\footnotetext{
${ }^{19}$ ARAÚJO, op. cit., p. 412.

${ }^{20}$ OEXLE, op. cit., p. 56.

${ }^{21}$ ARAÚJO, op. cit., p. 416.
} 
Tabela 1: Beneficiários das doações deixadas em testamento em quatro períodos, cidade de Mariana

\begin{tabular}{c|c|c|c|c|c|c|c|c|c|c}
\hline & \multicolumn{2}{|c|}{$1748-1773$} & \multicolumn{2}{c|}{$1774-1798$} & $1799-1823$ & $1824-1848$ & \multicolumn{2}{c}{ Total } \\
\hline & $\mathrm{N}$ & $\%$ & $\mathrm{~N}$ & $\%$ & $\mathrm{~N}$ & $\%$ & $\mathrm{~N}$ & $\%$ & $\mathrm{~N}$ & $\%$ \\
\hline Instituições religiosas & 29 & 65,91 & 26 & 68,42 & 16 & 55,17 & 7 & 22,58 & 78 & 54,93 \\
\hline Família & 7 & 15,91 & 5 & 13,16 & 14 & 48,28 & 23 & 74,19 & 49 & 34,51 \\
\hline Sem vínculo declarado & 11 & 25,00 & 10 & 26,32 & 8 & 27,59 & 10 & 32,26 & 39 & 27,79 \\
\hline Alma & 25 & 56,82 & 8 & 21,05 & - & - & - & - & 33 & 23,24 \\
\hline Pobres & 5 & 11,36 & 7 & 18,42 & 3 & 10,34 & 8 & 25,81 & 23 & 16,20 \\
\hline Escravos $^{22}$ & 4 & 9,09 & 3 & 7,89 & 4 & 13,8 & 6 & 19,35 & 17 & 11,97 \\
\hline Outro $^{23}$ & 3 & 6,82 & - & - & 1 & 3,45 & 4 & 12,9 & 8 & 5,63 \\
\hline
\end{tabular}

Fonte: LAMPEH, AHCSM. 1ํofício, inventários post-mortem. AHCSM, 1ํofício, livros de registro de testamento. FamilySearch, livros de assentamentos de óbitos da Paróquia de Nossa Senhora da Assunção, Catedral de Mariana.

Foram reunidas como doações religiosas aquelas destinadas às agremiações leigas, à construção, reforma ou ornamentação de igrejas, à Bula da Santa Cruzada $^{24}$ e aos Lugares Santos de Jerusalém. ${ }^{25}$ Assim como no caso lisboeta,

\footnotetext{
${ }^{22}$ Para esmolas a escravos, considerou-se apenas as doações de objetos ou pecúlio. As concessões de liberdade condicionada ou de alforria após a morte do proprietário não foram computadas devido ao complexo jogo de relações, interesses, conveniências, disputas e solidariedades envolvidas nesse tipo de transação, o que faz da alforria lavrada em testamento uma categoria de legado merecedora de tratamento particular que leve em consideração a agência dos escravizados e libertos e o papel da alforria para a manutenção do próprio sistema escravista. Sobre essa discussão, ver: FLORENTINO, Manolo. Sobre minas, crioulos e a liberdade costumeira no Rio de Janeiro, 1789-1871. In: FLORENTINO, Manolo (org.). Tráfico, cativeiro e liberdade (Rio de Janeiro, séculos XVII-XIX). Rio de Janeiro: Civilização Brasileira, 2005.; LIBBY, Douglas Cole; PAIVA, Clotilde de Andrade. Alforrias e forros em uma freguesia mineira: São José d’El Rey em 1795. Revista Brasileira de Estudos de População, vol 17, nº.1/2, jan-dez, 2000, pp. 17-46.; PAIVA, Eduardo França. Escravos e libertos nas Minas Gerais do século XVIII. São Paulo: Annablume, 1995.; LARA, Silvia Hunold. Campos da violência: escravos e senhores na Capitania do Rio de Janeiro (1750-1808). Rio de Janeiro: Paz e Terra, 1988.

${ }^{23}$ Incluídos hospitais (5), presos (1), assistentes do cônego (1), noivos necessitados de pecúlio para se casarem (1).

${ }^{24} \mathrm{~A}$ arrecadação da Bula da Santa Cruzada era feita nas paróquias pelos tesoureiros designados, as esmolas remetidas para Portugal eram divididas entre a Coroa e a Igreja e aplicadas na expansão da cristandade e na defesa e manutenção das praças mercantis no norte da África. FIGUEIREDO, Cecília Maria Fontes. Os esmoleiros do rei: a bula da Santa Cruzada e seus oficiais na capitania de Minas Gerais (1748-1828). Tese (Doutorado em História). Niterói: UFF, 2014.

${ }^{25}$ As esmolas recolhidas em nome da Terra Santa de Jerusalém eram destinadas aos interesses e projetos empreendidos pelos frades franciscanos nos Lugares Santos da Palestina. No Brasil, esses religiosos se hospedavam nos hospícios da Terra Santa e percorriam cidades próximas a essas instalações, arrecadando esmolas para as missões na Terra Santa. Embora os esmoleres franciscanos já estivessem presentes nas Minas desde o século XVII, o hospício da Terra Santa de Ouro Preto só foi fundado em 1726, seguido pelo de Sabará (1734),
} 
as instituições religiosas abocanharam, antes de qualquer outra categoria, a maior parte dos legados. ${ }^{26}$ Ressalte-se que nas Minas setecentistas as doações instituídas por particulares foram significativas para construção, manutenção e ornamentação dos templos. Em muitos casos, tais contribuições poderiam representar a maioria das despesas efetuadas, acarretando menores gastos para os cofres paroquiais e para as associações leigas. ${ }^{27} \mathrm{O}$ cruzamento dos dados demonstrou que quando direcionadas para igrejas ou irmandades, a maior parcela dessas doações ficava nos sodalícios da cidade, geralmente vinculados aos testadores, por serem estes frequentadores ou devotos do orago. Trata-se, nesses casos, da afirmação da imagem de devoto e de benfeitor, reforçando, ao mesmo tempo, a associação do seu nome a uma certa posição social, lhe conferindo notoriedade entre os pares. ${ }^{28}$

É interessante notar na hierarquia dos beneficiários que, ao passo que as igrejas foram amplamente beneficiadas pela generosidade dos testadores, a outra ponta dos beneficiários estava ocupada por pobres e escravos. Tal atitude é contrastante com a valorização dos pobres pelo discurso católico que os classificava como intercessores privilegiados pois estariam situados mais próximos da graça divina, tendo uma atuação eficaz para o alcance da misericórdia de Deus..$^{29}$ As esmolas destinadas à remediação da pobreza exaltavam, além disso, o comportamento compassivo do defunto, rendendo a ele uma "memória piedosa". ${ }^{30}$ Apesar dos ganhos simbólicos gerados pela assistência aos desafortunados, as dádivas destinadas a eles estiveram muito abaixo das convertidas para a Igreja. Talvez porque com a pobreza e a desigualdade não coubessem maiores preocupações sob o modelo cristão, afinal, aos privados de fortuna na vida terrena fora assegurada a salvação eterna. Estigmas associados à pobreza e à escravidão também impediam que a primazia do assistencialismo coubesse às categorias que ocupavam os últimos lugares sociais, ao questionar o merecimento de auxílio de grupos associados à vadiagem e à

de São João del Rei (1743) e do Serro Frio (por volta de 1750). VILLELA, Clarisse Martins. Hospícios da Terra Santa no Brasil. Tese (Doutorado em Arquitetura e Urbanismo). São Paulo: USP, 2015. pp. 126-141.

${ }^{26}$ ARAÚJO, op. cit., pp. 417-419.

${ }^{27}$ BOSCHI, Caio César. Os Leigos e o Poder: Irmandades leigas e política colonizadora em Minas Gerais. São Paulo: Ática, 1986. pp. 126-133.

${ }^{28}$ BARBOSA, Gustavo Henrique. Poderes locais, devoção e hierarquias sociais: a Ordem Terceira de São Francisco de Mariana no século XVIII. Tese (Doutorado em História). Belo Horizonte: UFMG, 2015. pp. 113-115.

${ }^{29}$ DARNTON, Robert. 0 grande massacre de gatos, e outros episódios da história cultural francesa. Trad. Sonia Coutinho. Rio de Janeiro: Graal, 1986. pp. 153-154.

${ }^{30}$ FRANCO, Renato. Pobreza e caridade leiga: as Santas Casas de Misericórdia na América Portuguesa. Tese (Doutorado em História). São Paulo: USP, 2011. pp. 261 e 280. 
desonra. ${ }^{31}$ Enfim, os pobres, "miseráveis, obrigados a aceitar com resignação o seu estatuto, recebem na razão proporcional da sua insignificância social."32 A sensibilidade filantrópica atenta aos anseios sociais muito raramente apareceu como motivação para as doações, o que pode ser visto também na baixa recorrência de doadores às instituições hospitalares.

A atenção aos desvalidos, em sua parca presença pulverizada por todo o período, era também numericamente inferior à doação à própria alma, mesmo com essa tendo ficado restrita ao século XVIII. A beneficência menos interessada direcionada aos pobres estava contraposta ao favorecimento da própria alma, conservador de um caráter individualista. A postura individualista é aqui entendida como a resistência ao desentesouramento necessário após a morte, de modo que, desejando seguir usufruindo da fortuna, muitos testadores a direcionavam parcial ou totalmente para o Além. Relações feitas com os predicados dos donatários para a alma apontaram que tal comportamento foi particularmente manifestado por testadores cujos vínculos familiares em Mariana eram escassos: apenas dois doadores eram nascidos nas Minas; somente sete viveram fora do estado de solteiros, dos quais, cinco eram casados e dois, viúvos; nove tinham filhos; todos os testadores com filhos declarados os nomearam como herdeiros da legítima, reservando apenas a parte de livre disposição para a alma; os demais nomearam a alma como herdeira universal, incluindo dois casados que não deixaram descendentes. Alexandre Pereira Daves observou que a maioria dos testadores solteiros e sem filhos de Sabará da primeira metade do Setecentos, por sinal vindos majoritariamente do norte de Portugal, nomeavam a alma como herdeira universal. O autor tratou essa conduta como o "enraizamento possível", ou, como esses homens empregaram meios para a perpetuação de sua memória, manipulando as ferramentas disponíveis, no caso, o investimento no Além, convertido em sufrágios sucessivos para sua alma. ${ }^{33}$

Observa-se, a partir do prisma da caridade, como a piedade da população em questão só muito tangencialmente contemplava anônimos e desconhecidos. Assim como as encomendas de missas para as almas anônimas do Purgatório, a assistência caritativa aos pobres também perdia, de um modo geral, para as categorias compostas por pessoas inseridas em alguma medida no círculo social do testador. ${ }^{34}$ Apesar da doutrina católica estimular a

\footnotetext{
${ }^{31}$ Ibidem, pp. 232 e 263.

${ }^{32}$ ARAÚJO, op. cit., p. 417.

${ }^{33}$ DAVES, op. cit., p. 195.

${ }^{34}$ Sobre o encolhimento dos subsídio às almas anônimas do Purgatório, ver: CAMPOS, Adalgisa Arantes. As irmandades de São Miguel e as almas do purgatório: culto e iconografia no setecentos mineiro. Belo Horizonte: C/ Arte, 2013. p. 133.; FERREIRA, op. cit., pp. 83-84.
} 
distribuição de esmolas sob o mote da virtude da caridade, a seleção dos beneficiários pelos doadores era feita a partir de parâmetros fornecidos pelas relações sociais mais imediatas..$^{35}$ Essa sensibilidade que recusava categorias universalizantes, tais como pobres, estava, ao contrário, direcionada para a esfera local e para pessoas próximas, o que explica a frequência das preferências dos testadores. Todos os beneficiários incluídos em sem vínculo declarado foram nomeados ou identificados por outros meios pelos doadores. Eram, pois, pessoas específicas, individualizadas no ato da definição da esmola, não eram desconhecidas ou agrupadas em categorias comuns. Embora entre testadores e esses destinatários das esmolas houvesse algum tipo de proximidade, na menor parte das vezes a natureza desse vínculo foi declarada. De todo modo, essa categoria, não obstante não ter sido composta por parentes - consanguíneos ou espirituais -, tampouco foi formada por anônimos.

A família, reunindo parentesco sanguíneo (30 doadores ou 21,13\%) e espiritual, na figura dos afilhados ( 25 ou 17,61\%), apareceu como o segundo grupo a angariar mais legados testamentários. Entre os diferentes elementos da preocupação com a assistência à família, a par da pressão pela não dilapidação do patrimônio familiar e dos constrangimentos legais em torno da herança, concorriam, seguramente, componentes de ordem afetiva e moral. Desencargo de consciência ${ }^{36}$, retribuição de favores ou serviços ${ }^{37}$, compensação pelo companheirismo ${ }^{38}$, "boa vontade" ${ }^{39}$, demonstração de confiança ${ }^{40}$,

\footnotetext{
${ }^{35}$ SANTANA, op. cit., p. 153.

36 "Deixo o resto da minha terça a todas as minhas filhas e filhos para desencargo de minha consciência." AHCSM. Ano 1817, Códice 94, auto 1964, 1º ofício. LAMPEH. Inventário com testamento de João Duarte Pinto [1817].

37 "Item que a minha terça aquillo que soubrar das minhas dispozicoens e sufragios deixo a meos filhos Joaquim e Antonio aos quaes lhes sou devedor de certa quantia de porçoens do tempo que forão meos feitores como consta das obrigaçoens que passei aos mesmos." AHCSM. Ano 1827, Códice 128, auto 2688, $1^{\circ}$ ofício. LAMPEH. Inventário com testamento de Francisco Moreira de Faria [1826].

${ }^{38}$ José Vicente Ferreira Baracho, tendo nomeado filha e neta herdeiras, deixou sua terça para sua afilhada e testamenteira em sinal de gratidão pela assistência de muitos anos que ela lhe deu na doença. AHCSM. Ano 1844, Códice 83, auto 1765, 1ํo of́́cio. LAMPEH. Inventário com testamento de José Vicente Ferreira Baracho [1844].

${ }^{39}$ Antônio Corrêa Machado dotou uma exposta que assistia em sua companhia com $200 \$ 000$ réis, ordenou que seu testamenteiro a vestisse enquanto ela fosse solteira e lhe deixou uma casa. AHCSM. Ano 1809, Códice 12, auto 411, 1ํo ofício. LAMPEH. Inventário com testamento de Antônio Corrêa Machado [1805].

40 "Declaro que satisfeitas as minhas dividas e o mais declarado em meu testamento do que restar se fara a minha terça e desta deixo por herdeyra a minha mulher Dona Clara Maria a nam reservo nada della para suffragios de minha alma por confiar da dita minha mulher fara como espero della." AHCSM. Ano 1757, Códice 118, auto 2455, 1o ofício. LAMPEH. Inventário com testamento de Guilherme Nunes [1757].
} 
e cuidado com sobrevivência material e boa harmonia dos filhos ${ }^{41}$ : foram, cada um a seu modo e com variações possíveis, motivações para a reserva de parte ou do total da terça do testador para seus familiares.

Independentemente das razões particulares atuantes na conversão da parte da livre disposição para o patrimônio familiar, o ato da doação não esteve necessariamente dissociado das expectativas salvacionistas. Como já colocado, as esmolas tradicionalmente foram incentivadas pela Igreja como exercício da virtude da caridade, além de que costumeiramente parentes e favorecidos assumiam como compromisso a realização de missas ou orações pela alma do doador..$^{42}$ Mas, para além do religioso, lançando mão da livre disposição da terça, testadores estiveram possibilitados a avolumar a legítima dos herdeiros ou contemplar pessoas que a princípio não seriam beneficiadas pela herança. ${ }^{43}$ Cuidados com a sobrevivência e reprodução material e social da família e de entes queridos despontavam no engajamento para provisão de incremento ou de estabilidade dos favorecidos. Ainda que estas, portanto, não contrariassem a dimensão religiosa, cabe observar que o favorecimento de particulares resultava em assistência temporal às pessoas eleitas e se prestava à função social de reforço da coesão grupal.

A distribuição das categorias de agraciados pelos doadores comportou traços de permanência, mas indicou também mudanças de comportamento visíveis nos dados da tabela. Começando pelos grupos menos beneficiados pobres, escravos e outros - a baixa recorrência verificada impediu que qualquer sugestão de mudança, ou de continuidade, fosse amparada empiricamente. $\mathrm{O}$ anúncio de que o remanescente da terça seria direcionado para a alma, por sua vez, foi se extinguindo junto à prática de sua nomeação como herdeira universal. Os testamentos rapidamente se adequaram à legislação pombalina, e até a década de 1770 foi recorrente o encerramento dos acertos religiosos com a expressão "em conformidade com as Leis Novíssimas". Os bens de alma, para os quais ainda estava disponível a tercinha, deixaram de ser definidos a partir de reservas de montantes ou de parcelas do patrimônio, como foi bastante comum nas primeiras décadas do recorte cronológico.

\footnotetext{
${ }^{41}$ José Rodrigues Duarte destinou sua parte da terça para os filhos, pedindo que eles beneficiassem sua alma, não sendo ingratos e que conservassem "boa armonia" em relação à herança. AHCSM. Ano 1798, Livro de Registro de Testamentos $\mathrm{n}^{\circ} 45,1^{\circ}$ ofício. Testamento de José Rodrigues Duarte [1798].

${ }^{42}$ DAVES, op. cit., p. 194.

${ }^{43}$ SILVA, Maria Beatriz Nizza da. História da Família no Brasil Colonial. Rio de Janeiro: Nova Fronteira, 1998. pp. 201 e 244.
} 
As três categorias mais recorrentes direcionaram a atenção para a observação de alguns deslocamentos. A mudança mais sensível se deu com os legados às pessoas específicas, mas sem vínculo familiar explicitado. Houve um progressivo, mas bastante ligeiro crescimento dos testadores que deixaram doações a pessoas conhecidas, possivelmente amigas, vizinhas, parceiras em negócios, favorecidas, ou mesmo parentes cujo parentesco não foi declarado.

De outro modo, os dois primeiros grupos preferidos na distribuição de legados registraram mudança substantiva e sugestiva de uma sobreposição de objetos de preocupação. Como pode se observar, ainda que em termos gerais as doações religiosas tenham se mantido como a mais recorrente, elas registraram ao longo do tempo um declínio paulatino, deixando, no segundo quarto do século XIX, de serem as maiores beneficiárias da piedade dos homens e mulheres em sua preparação para a morte. Nesses anos finais do recorte, a dianteira anteriormente assumida pelas igrejas e agremiações leigas foi transferida para o universo familiar.

Esse longo processo, que acarretava uma lenta redução dos bens da Igreja, muito possivelmente carregou o impacto a longo prazo da regulação pombalina. Contudo, de modo semelhante ao movimento que acompanhou as transformações na herdade verificadas por Alexandre Pereira Daves, o enraizamento constituiu fator estrutural. Os dados encontrados pelo autor demonstraram um processo de crescimento de instituição de parentes como herdeiros em detrimento da alma anterior à 1766, que as leis pombalinas apenas teriam feito acelerar. ${ }^{44}$ No que cabe à documentação recolhida para a presente investigação, esse alto índice de doadores destinando legítimas para familiares foi atingido na altura em que a presença de nascidos em Mariana correspondia a cerca de três quartos dos testadores e a taxa de "celibatários" deixava de representar maioria. Ou seja, tratava-se naquele momento de uma população testamentária muito mais enraizada localmente do que nos períodos anteriores. Em resumo, e ratificando as observações do autor acima citado, está-se diante de uma relação de condicionamento mútuo entre domínios religioso e familiar. ${ }^{45}$

As perspectivas salvacionistas foram, com o passar do tempo, reforçando a manutenção dos laços familiares e a valorização da perenidade dos vínculos terrenos. 0 modelo de caridade testamentária se desenrolou, desenhando um movimento de sobreposição da solidariedade familiar sobre o investimento direto na própria alma ou na promoção do culto e do enriquecimento da

${ }^{44}$ DAVES, op. cit., pp. 179-180.

${ }^{45}$ Ibidem, p. 180. 
Igreja. Um dos testemunhos registrados na documentação mais ilustrativos a esse respeito talvez seja o de José Rodrigues Duarte que, viúvo e pai de três filhos, destinou o remanescente de sua terça aos herdeiros e recomendou:

Espero $\mathrm{q}^{\wedge}$ os ditos meus filhos e herdeiros fação boa armonia e uniam afim $\mathrm{deq}^{\wedge}$ não tenhão desordens nem demandas sobre a herança Materna nem nesta minha porq ${ }^{\wedge}$ assim como Pai lhes recomendo vivão em paz e escuzem litigios oq cumprirão como bons filhos e irmaons. [...] e todo o remanecente $\mathrm{q}^{\wedge}$ sobar da dita minha terça a deixo aos ditos meus tres filhos herdros na partida em igual parte esperando $q^{\wedge}$ elles fação pella minha alma oq $q^{\wedge}$ devem como bons filhos $\mathrm{p}^{\mathrm{a}} \mathrm{q}^{\wedge}$ Deos os ajude e favoreça não sendo ingratos $\mathrm{p}^{\mathrm{a}}$ seu Pai. ${ }^{46}$

A doação da terça aos filhos é demonstrativa da preocupação com a vida material da família. A solidariedade familiar, ao se preocupar em garantir as condições materiais de sobrevivência, também se voltava para o cuidado com a coesão grupal, demonstrada pelo pedido de que os irmãos conservassem a união após sua morte. $O$ pedido de que os filhos não fossem ingratos e retribuíssem a alma do pai falecido é expressão da permanência dos rituais fúnebres e da crença em sua eficácia. O excerto não possui elementos sugestivos de abandono das práticas e concepções da boa morte, o que ele revela é a subordinação da esfera religiosa à chancela da família. ${ }^{47}$ Às mesmas considerações foi levado Gaël Rideau por meio da análise da expressão testamentária em Orleans, as quais são reproduzidas a seguir:

La dimension familiale envahit même le religieux et en constitue une nouvelle voie. Implicite chez beaucoup, le bourgeois Michel Benoît de Ligny l'explicite. Son testament s'ouvre sur un état de conscience, puisque «après avoir réfl échi devant Dieu sur les biens qu'il luy a plu me départir, j'ay cru devoir pour entretenir la paix et l'union entre mes cinq enfants». Cette affi rmation est à relier à la sollicitation du testateur qui «n'ordonne point de messes ny de prieres pour le repos de [son] ame dans la confiance que [ses] enfants le feront par eux-mêmes». Le religieux ne disparaît pas, il s'insère dans une logique familiale hors de la sphère testamentaire. Plus qu'un détachement, il s'agit d'une nouvelle expression, d'un glissement. Dès lors, la disparition de l'exprimé ne signifi e pas forcément celle de la pratique. ${ }^{48}$

As mudanças que operaram na redação do documento de última vontade se deram antes no âmbito da expressão e da atribuição do que no das práticas.

\footnotetext{
${ }^{46}$ AHCSM. Ano 1798, Livro de Registro de Testamentos $n^{\circ} 45$, 1o ofício. Testamento de José Rodrigues Duarte [1798].

${ }^{47}$ Ver estudo mais detalhado em: FERREIRA, op. cit.

${ }^{48}$ RIDEAU, Gaël. Pratiques testamentaires à Orléans, 1667-1787. Revue d'histoire moderne et contemporaine. n 57-4, 2010. pp. 118-119.
} 
A organização discursiva que passou progressivamente a ser adotada pelos testadores - que, diga-se de passagem, não era efetivamente nova no período estudado, mas constituía opção verdadeiramente preterida frente à solidez e ampla difusão das cláusulas diretamente religiosas - trouxe paulatinamente a família e seus interesses para a espinha dorsal do registro. No campo da disposição da terça na forma de legados, que por ora é o foco da análise, observa-se a piedade post-mortem, no avançar do Oitocentos, assumindo formas mais familiares do que religiosas. 0 espaço que em grande parte dos registros setecentistas se dedicava ao favorecimento da alma por meio da capitalização dos bens adquiridos em vida para o além-túmulo, prática factível graças às instituições religiosas, foi cedendo lugar, como no testamento de José Rodrigues Duarte, anteriormente citado, para o desejo de amparo e concórdia familiar.

A leitura das solidariedades póstumas relatadas nas doações testamentárias - assim como das demais práticas fúnebres, diga-se de passagem - não foi reveladora de imobilidades, tampouco de rupturas bruscas. Assim como lembrou Michel Vovelle, os comportamentos relativos à morte e aos mortos são constituídos por um conjunto de estratificações, de modo que certas atitudes podem registrar uma persistência plurissecular e diferentes modelos podem atuar simultaneamente. Diante disso, o autor se propôs a falar em estratificações ou "deslizamentos" " ${ }^{49}$ É nesses termos que se tem tentado interpretar as informações obtidas ao longo dessa investigação. A escolha dos beneficiários de doações testamentárias demonstrou não um desaparecimento do cuidado religioso, mas sua circunscrição à lógica e ao campo familiares.

A preocupação com o amparo das pessoas próximas que sobreviveriam à morte do testador já ocupava papel significativo em meados do Setecentos, o que é visto pela alta taxa de nomeação de parentes como herdeiros mesmo antes da legislação pombalina e pela tímida, mas já presente, doação a familiares. Embora seja absolutamente não desprezível a presença familiar nos testamentos dos anos iniciais do recorte em tela, o individualismo testamentário ainda se afirmava como expressão mais hegemônica. O recurso adotado para a transformação de bens materiais em espirituais acabava transferindo montantes para a comunidade de natureza religiosa através das disposições pias, que eram convertidos em serviços fúnebres em memória do morto. ${ }^{50}$ Posto de outro modo, o individualismo testamentário lançava mão da memória litúrgica como meio de salvação por excelência. Estratégia fortalecida e especialmente

\footnotetext{
${ }^{49}$ VOVELLE, Michel. A história dos homens no espelho da morte. In: BRAET, Herman \& VERBEKE, Werner (eds.). A Morte na Idade Média. Trad. Heitor Megale, Yara Frateschi Vieira, Maria Clara Cescato. São Paulo: Edusp, 1996. p. 16.
}

${ }^{50}$ DAVES, op. cit., p. 177. 
valorizada, é importante ressaltar, pela população migrante e celibatária, que, menos enraizada localmente, encontrava na atuação da comunidade religiosa uma forma de se fazer lembrar através das celebrações encomendadas.

Se o individualismo testamentário já não era irrestrito em inícios do recorte cronológico em tela, ele foi sendo paulatinamente cerceado pela valorização da família em curva ascendente. A crescente instituição de doações a parentes (consanguíneos ou espirituais) e, em menor monta, a pessoas conhecidas, é comportamento sugestivo de sociabilidades mais sólidas entre indivíduos que as passaram à prioridade em detrimento da comunidade religiosa. "O testamento passa também a estabelecer laços de solidariedade, voltados para a existência terrena e cunhados na sobrevivência dos entes que aqui ficaram, e ao mesmo tempo reificados na memória dos seus defuntos." ${ }_{11}$ Assim, a sobreposição observada nas fontes parece ser expressão, como tem-se tentado argumentar, de um processo mais abrangente de enraizamento e de reforço dos laços familiares.

Esse deslocamento nada mais é do que a sobreposição progressiva de uma preocupação também de natureza mnemônica, mas que, por sua vez, se sustentava pela recordação dos próximos. Em outros termos, assiste-se à emergência gradual da sociabilidade familiar como administradora da lembrança do morto. As esmolas póstumas, especialmente no caso de testadores mais desenraizados, foram direcionadas para sociabilidades de natureza religiosa, como recurso que se prestava ao alargamento da memória, deixaram ver sua expressão na forma litúrgica, como meio de reafirmação de filiação devocional ou distinção social. Conforme se avançava no século XIX, diante de uma população mais enraizada, a coesão e a solidez das relações familiares, que se prolongavam para além da morte, começaram a ser remetidas em primeiro plano. O investimento pessoal reservado aos próximos continuava podendo ser convertido em memória litúrgica, na forma de preces, missas e orações como retribuição de afeto ou generosidade, mas antes disso, ela era um cuidado familiar. Nesse sentido, se observa que a piedade, na medida em que assumia formas mais familiares, demonstrava a existência de sociabilidades mais sólidas que carregavam formas mais eficazes de lembrança. A crescente atenção no momento da morte para a coesão grupal indica a valorização do papel da memória dos próximos como mecanismo de sobrevida.

Artigo recebido para publicação em 14/09/2019 Artigo aprovado para publicação em 09/02/2020

${ }^{51}$ Ibidem, p. 67. 